УДК 347.73

DOI https://doi.org/10.32849/2663-5313/2020.8.31

Павло Коломієць,

канд. юрид. наук, дочент,

доцент кафедри правознавства

Полтавського інституту економіки і права

\title{
ПРОБЛЕМАТИКА МЕТОДОЛОГІЇ ДОСЛІДЖЕННЯ ПРАВОВОГО РЕГУЛЮВАННЯ ПОДАТКОВОЇ БЕЗПЕКИ УКРАЇНИ: КОНЦЕПТУАЛЬНІ ОСОБЛИВОСТІ
}

Метою статті є характеристика кониептуальних особливостей проблематики методології дослідження правового регулювання податкової безпеки України. Основне завдання методології дослідження повинно полягати в забезпеченні наукового пізнання системою строго вивірених і таких, що пройшли апробачію, принципів, методів, правил і норм діяльності науковия. Варто наголосити, що кониептуальною особливістю проблематики методології дослідження правового регулювання податкової безпеки України є відсутність «системи строго вивірених і таких, що пройщли апробачію, принципів, методів, правил і норм діяльності науковия» з даного напряму наукового пізнання.

Отже, для досягнення успіху у свойй дослідницькій діяльності стосовно пізнання проблематики правового регулювання податкової безпеки України, автор повинен був опанувати «евристичну технологію правового мислення».

У процесі виконання основного завдання даного дослідження визначено, що наукове пізнання правового регулювання податкової безпеки в Україні забезпечено системою методів, сформованих на основі сучасних реалій суспільних відносин у сфері податкової безпеки.

Результати дослідження кониептуальних особливостей проблематики методології дослідження правового регулювання податкової безпеки України свідчать про те, що головною віссю начіональної безпеки є податкова безпека, адже всі галузі начіональної безпеки спираються на фінансування з державного бюджету, найвагомішим наповнювачем якого є податки.

Як відомо, міиність ланиюга вимірюеться найслабшою його ланкою. 3 точки зору начіональної безпеки як ланиюжка маємо констатувати, що його найслабшою ланкою виступає податкова безпека. Дане явище проявляється у неможливості потужного наповнення державного бюджету, зокрема, через наявні ризики, що загрожують податковій безпеці.

Складається враження, що про податкову безпеку України за весь час незалежної України воліли не згадувати. На нашу думку, період незалежності України можна назвати періодом суцільної прокрастиначії стосовно правового забезпечення податкової безпеки.

Ключові слова: Податковий кодекс України, податкова безпека, економічна безпека, національна безпека, методологія дослідження.

Постановка проблеми. Основне завдання методології дисертаційного дослідження повинно полягати в забезпеченні наукового пізнання системою строго вивірених і таких, що пройшли апробацію, принципів, методів, правил і норм діяльності науковця.

У юридичній науці поняття «методологія» використовується в двох значеннях по-перше, як система принципів і способів, що використовується дослідником у своїй теоретичній та практичній діяльності для вивчення проблем права; по-друге, як вчення про цю систему, що забезпечує науковий пошук відповідей на виникаючі перед дослідником питання [1].
Варто наголосити, що концептуальною особливістю проблематики методології дослідження правового регулювання податкової безпеки України є відсутність «системи строго вивірених і таких, що пройшли апробацію, принципів, методів, правил і норм діяльності науковця» 3 даного напряму наукового пізнання. Тому для досягнення успіху у своїй дослідницькій діяльності стосовно пізнання проблематики правового регулювання податкової безпеки України автор повинен був опанувати «евристичну технологію правового мислення» [1].

Евристика (від грецьк. - знаходжу) термін, яким позначають галузь знання про 
творчу діяльність, пов'язану 3 пошуками шляхів відкриття нового в судженнях, ідеях, способах діяння. Основним завданням евристики є створення моделей пошуку нового розв'язання завдання. Евристичні моменти виявляються тоді, коли наявні умови не підказують людині способу розв'язання певного завдання і минулий досвід не містить у собі готової схеми, що могла би бути застосована за даних умов. Для виходу з проблемної ситуації створюють нову стратегію діяльності [2, с. 183].

Аналіз останніх досліджень i публікацій. М. О. Баймуратов у науковому пошуку щодо дискреційних повноважень органів місцевого самоврядування дослідив методологічні підходи до їх розуміння та визначення, зазначивши, що дискреція виникае як об'єктивна та природна потреба посадової (службової) особи або уповноваженого органу діяти на свій розсуд, без узгодження з будь-яким іншим суб'єктом, з метою більш чіткого та якісного виконання зазначених повноважень [3].

Досліджуючи співвідношення відносин щодо забезпечення економічної безпеки 3 адміністративно- і господарсько-правовими відносинами Б. В. Деревянко порівняв напрями досліджень відносин із забезпечення економічної безпеки суб'єктів господарювання в межах економічних і правових наук. Науковцем запропоновано розглядати правові відносини із забезпечення економічної безпеки суб'єктів господарювання 3 використанням механізмів різних правових наук і в межах нової юридичної наукової спеціальності [4]

Д. А. Керимов у своїй монографії «Методологія права (предмет, функції, проблеми філософії права)» докладно аналізує шляхи, методи і засоби дослідження одного зі складних соціальних феноменів - права. Автор виходить із того, що методологічну функцію в правознавстві покликана виконувати насамперед філософія права - один з основних напрямів загальної теорії права [5].

T. А. Латковська стверджує, що основними методами дослідження, які застосовуються наукою фінансового права, є: формально-догматичний, порівняльно-правовий, історико-правовий, соціологічний, структурно-функціональний тощо. Шляхом застосування формально-догматичного методу здійснюються тлумачення та класифікація сукупності фінансово-правових норм, їх втілення у нормативно-правових актах та реалізація у практиці правозастосування. Порівняльно-правовий метод дозволяє розкрити сутнісні ознаки фінансово-правових явищ у різних правових системах, є способом перенесення та ефективного впровадження переваг і здобутків аналогічних зарубіжних моделей фінансово-правового регулювання у вітчизняну практику. Історико-правовий метод дозволяє виявити тенденції виникнення і розвитку різних фінансово-правових процесів і їх правове регулювання. Наявні проблеми сучасного фінансового права можуть бути вирішені лише з урахуванням накопиченого у минулому досвіду, з вивченням положень та висновків, сформульованих фінансово-правовою наукою на попередніх етапах іiі становлення. Соціологічний метод у науці фінансового права вказує на їі взаємозв'язок і взаємозумовленість 3 правовою практикою. Структурно-функціональний метод наукового пізнання у науці фінансового права є сукупністю логічних прийомів і засобів дослідження структури певного явища шляхом характеристики системних зв'язків, взаємодії та функціонування елементів цієї структури. Даний метод широко застосовується у фінансово-правовій науці, оскільки дозволяє чітко структурувати знання про фінансове право як систему відповідних правових норм та інститутів. Предмет, мета і методи дослідження зумовлюють зміст знань, що становлять науку фінансового права і систематизують ці знання [6].

У дослідженні І. С. Луценко висвітлено методичний підхід до оцінювання рівня податкової безпеки держави як стратегічного складника фінансової безпеки держави, що, на думку вченої, дозволить започаткувати об'єктивний та якісний регулярний моніторинг рівня податкової безпеки держави та запропонувати заходи щодо зміцнення податкової безпеки держави, визначити загрози, які найбільш суттєво впливають на виявлені негативні довгострокові тенденції [7].

Ю. М. Оборотов, дослідивши аспекти розгортання методології юриспруденції, стверджує, що відбувся рух у самому розумінні змісту методології юриспруденції до з'єднання інструментального та функціонального призначення методології. Показовим у цьому сенсі, вказує автор, є обгрунтування у дисертаційних дослідженнях різноманітних підходів, що становлять сучасну методологію юриспруденції. Серед найбільш характерних для сучасних розробок, зауважує науковець, можуть бути названі такі підходи, як антропологічний, аксіологічний, цивілізаційний, синергетичний і герменевтичний. По суті, кожен із названих підходів визначає стратегію дослідних пошуків у взаємозв'язку юриспруденції з правом і державою. Автор констатує, що сучасна методологія юриспруденції плюралістична за своєю природою, оскільки стверджує наявність різних підходів 
до одного й того ж об’єкта: права і держави. Водночас це розмаїття підходів є свідченням переходу методології юриспруденції на новий рівень розвитку. Чим більше підходів пропонує методологія до осягнення об'єкта, резюмує Ю. М. Оборотов, тим ширші можливості для його багатогранного аналізу юридичною наукою і тим вищою є ефективність наукових досліджень права і держави [8].

М. I. Панов у своєму дослідженні «Проблеми методології формування категоріально-понятійного апарату юридичної науки» констатує, що юридична наука за своїм змістом становить відносно розвинену систему упорядкованих знань про державноправові явища, закономірності їх існування i розвитку. Системоутворюючими елементами цієї науки виступають: наукові гіпотези, правові ідеї і теорії (спеціальні теорії), концепції, методи, методики і принципи наукового пізнання, правові інститути, норми і юридичні конструкції, факти і явища правової реальності [9].

Підсумовуючи результати дослідження деяких сучасних тенденцій методології вітчизняного загальнотеоретичного праводержавознавства, П. М. Рабінович зазначає, що трансформаційні зрушення у методології вітчизняного правознавства, поряд iз певними позитивними здобутками, не позбавлені й деяких спільних для них проблем. До останніх належить, зокрема, те, що у виборі та застосуванні окремих дослідницьких методів і засобів подекуди має місце відхід від доведених суспільним досвідом аксіоматичних постулатів наукового пізнання - насамперед таких, як-от: зумовленість вибраних методів дослідження його предметом; обов'язковість встановлення об'єктивної істини, достовірність якої можна довести і перевірити, спираючись на такий досвід як на її надійний об'єктивний критерій; необхідність виявлення соціальної сутності правових і державних явищ. Науковець підкреслює, що більшість із новелізованих підходів і методів юридичної науки являють собою не що інше, як сучасну, зумовлену соціально-природними змінами й приростом наукових знань, подальшу конкретизацію класичних принципів і вимог діалектики - «вічнозеленої» пізнавальної парадигми будь-якої теорії [10].

Досліджуючи проблеми розвитку методології права, О. І. Ющик стверджує, що соціально-економічні й політичні процеси останніх десятиліть у країнах Східної Європи та СНД суттєво вплинули на розвиток суспільної свідомості в цих країнах, що характеризується докорінним руйнуванням соціально-психологічних та ідеологічних стереотипів. Не залишилися незайманими також правосвідомість і праворозуміння. При цьому ревізуються не якісь другорядні висновки юридичної науки, йдеться про упровадження принципово нових, відмінних від попередніх, концепцій розуміння права як соціального явища, про піднесення його на інший рівень на основі так званої сучасної методологічної бази. А проте переконливих теоретичних здобутків від вказаної ревізії юридична наука за більш як два десятиліття все ще не має. Це, стверджує О. І. Ющик, дає підстави для висновку не просто про методологічну кризу в сучасній юридичній науці, а про повернення розвитку методології пізнання права у напрямі регресу [11]. У зв'язку 3 цим виникає потреба у критичному осмисленні сучасної методологічної бази на предмет відповідності останньої закономірностям розвитку методології пізнання права.

Метою статті $є$ характеристика концептуальних особливостей проблематики методології дослідження правового регулювання податкової безпеки України.

Виклад основного матеріалу. Починаючи зі здобуття незалежності в Україні ухвалено три нормативно-правові акти, які безпосередньо стосуються правового регулювання суспільних відносин у сфері національної безпеки, а саме:

1) Постанова Верховної Ради України від 16.01.1997 року № 3/97-ВР «Про Концепцію (основи державної політики) національної безпеки України» [12];

2) Закон України від 19.06.2003 року № 964-IV «Про основи національної безпеки України» [13];

3) Закон України від 21.06.2018 року № 2469-VIII «Про національну безпеку України» [14].

Проте у жодному з них немає і згадки про податкову безпеку України. Складається враження, що про податкову безпеку України за весь час незалежної України воліли не згадувати.

На нашу думку, період незалежності України можна назвати періодом суцільної прокрастинації стосовно правового забезпечення податкової безпеки.

Прокрастинація - це зволікання, акт непотрібного відстрочення завдань до рівня відчуття суб'єктивного дискомфорту [15].

У процесі виконання основного завдання даного дослідження визначено, що наукове пізнання правового регулювання податкової безпеки в Україні забезпечено системою методів, сформованих на основі сучасних реалій суспільних відносин у сфері податкової безпеки. 
Використання діалектичного методу пізнання суспільних відносин, що виникають у сфері застосування податкової безпеки, дозволило об'єктивно оцінити справжній стан правового регулювання податкової безпеки в його історичному розвитку як об'єктивного процесу становлення цього правового явища у всій повноті його форми 3 притаманним йому суперечностями та визначити доцільність цивілізаційних витоків його зародження, утворення, становлення та існування в Україні.

Системний метод надав можливість розглянути правове явище - податкову безпеку - в контексті історико-правових засад виникнення і розвитку її правового регулювання. 3 цією метою із загального масиву податкового законодавства України були відібрані та систематизовані нормативні акти, що прямо чи опосередковано стосуються або регулюють суспільні відносини у сфері податкової безпеки.

Дієвим інструментом для вирішення поставленого завдання став метод наукового дослідження - історико-правовий метод теоретичного пошуку, за допомогою якого у хронологічній послідовності проведено всебічне дослідження генези і закономірностей розвитку законодавства у сфері правового регулювання податкової безпеки в Україні.

Для впорядкування різноманітного нормативно-правового матеріалу у сфері податкової безпеки застосовано метод періодизації.

Керуючись науковим методом комплексного аналізу змін, що відбувалися у законодавчій царині податкової безпеки, та для пояснення i обгрунтування застосованих нами способів впорядкування масиву законодавчого матеріалу за просторовими критеріями періодизації автором було застосовано теоретичний науковий метод гіпотези як форми пізнання сучасної наукової проблеми правового регулювання податкової безпеки, яка ще не слугувала предметом наукових пошуків вітчизняних науковців-юристів.

На основі результатів теоретичного методу аналізу нормативно-правових актів органів влади у сфері податкової безпеки України простежено процес формування правових засад податкової безпеки та з'ясовано місце правового регулювання податкової безпеки в проблематиці відповідності податкової політики держави викликам сучасності.

На підставі такого методу наукового пізнання, як класифікація, здійснено розподіл, групування та систематизацію законодавчого матеріалу за певними ознаками, факторами й критеріями, що стало підгрунтям авторської періодизації основних віх історії становлення, формування і розвитку законодавства у сфері правового регулювання податкової безпеки України.

Для дослідження історико-правових аспектів становлення і розвитку законодавства у сфері правового регулювання податкової безпеки України використано формально-правовий метод. Застосування цього методу забезпечило можливість отримання достовірних результатів наукового пошуку шляхом опису, класифікації й систематизації, формулювання, пояснення, аргументації і критики визначення понять нормативноправових актів у сфері правового регулювання податкової безпеки.

\section{Висновки}

Результати дослідження концептуальних особливостей проблематики методології дослідження правового регулювання податкової безпеки України свідчать про те, що головною віссю національної безпеки є податкова безпека, адже всі галузі національної безпеки спираються на фінансування з державного бюджету, найвагомішим наповнювачем якого є податки.

Як відомо, міцність ланцюга вимірюється найслабшою його ланкою. 3 точки зору національної безпеки як ланцюжка маємо констатувати, що його найслабшою ланкою виступає податкова безпека. Дане явище проявляється у неможливості потужного наповнення державного бюджету, зокрема через наявні ризики що загрожують податковій безпеці.

\section{Список використаних джерел:}

1. Гуляихин В.Н. К вопросу о методологии диссертационных работ в юридической науке. Юридические исследования. 2012. № 1. С. 92-106.

2. Філософський енциклопедичний словник / В.І. Шинкарук (гол. редкол.) та ін. Київ: Абрис, 2002. 742 с.

3. Баймуратов М.О. Дискреційні повноваження органів місцевого самоврядування в сфері захисту прав людини: методологічні підходи до розуміння та визначення. Публічне право. 2019. № 2. С. 31-41.

4. Деревянко Б.В. Соотношение отношений по обеспечению экономической безопасности с административно- и хозяйственно-правовыми отношениями. Проблеми правознавства та правоохоронної діяльності. 2014. № 4 (51). С. 168-176.

5. Керимов Д.А. Методология права (предмет, функции, проблемы философии права) 2-е изд. Москва: Аванта,+ 2001.560 с

6. Латковська Т.А. Розвиток науки фінансового права - запорука розвитку Української держави. Наукові праиі Начіонального університету «Одеська юридична академія». 2012. Т. 12. С. 9-18. 
7. Луценко I.C. Методичний підхід до оцінювання рівня податкової безпеки держави. Науковий вісник Херсонського державного університету. Серія «Економічні науки». 2015. Вип. 12(2). С. 159-163.

8. Оборотов Ю.М. Аспекти розгортання методології юриспруденції. Право Украӥни. 2014 № 1. С. $33-39$.

9. Панов М.І. Проблеми методології формування категоріально-понятійного апарату юридичної науки. Право Украӥни. 2014. № 1. С. 50-60.

10. Рабінович П.М. Методологія вітчизняного загальнотеоретичного праводержавознавства: деякі сучасні тенденції. Право України. 2014. № 1. C. $11-21$.

11. Ющик О.I. До проблеми розвитку методології права. Право Украйни. 2014. № 1. С. 40-49.
12. Про Концепцію (основи державної політики) національної безпеки України : Постанова Верховної Ради України від 16.01.1997 року № 3/97-ВР. Відомості Верховної Ради України. 1997. № 10. Ст. 85.

13. Про основи національної безпеки України: Закон України від 19.06.2003 року № 964-IV. Відомості Верховної Ради Украйни. 2003. № 39. Ст. 351.

14. Про національну безпеку України: Закон України від 21.06.2018 року № 2469-VIII. Відомості Верховної Ради Украйни. 2018. № 31. Ст. 241. 15. Solomon L.J., Rothblum E.D. (1984). Academic procrastination: Frequency and cognitivebehavioral correlates. Journal of Counseling Psychology, 31. P. 503-509.

Pavlo Kolomiiets. Problems of the methodology for researching the legal regulation of Ukraine's tax security: conceptual features

The purpose of the article is to characterize the conceptual features of the methodology of research of legal regulation of tax security of Ukraine. The main task of the research methodology should be to provide scientific knowledge of a system of strictly verified and tested principles, methods, rules and norms of the scientist. It should be emphasized that the conceptual feature of the methodology of research of legal regulation of tax security of Ukraine is the lack of "system of strictly verified and tested principles, methods, rules and norms of the scientist" in this area of scientific knowledge.

Therefore, in order to succeed in his research activities on knowledge of the legal regulation of tax security of Ukraine, the author had to master the "heuristic technology of legal thinking."

Performing the main task of the methodological foundations of this study, scientific knowledge of the legal regulation of tax security in Ukraine is provided by a system of methods formed on the basis of modern realities of public relations in the field of tax security.

The results of the study of the conceptual features of the methodology of research of legal regulation of tax security of Ukraine show that the reference axis of national security is tax security, because all areas of national security are based on funding from the state budget, the most important filler of which is taxes.

It is known that the strength of a chain is measured by its weakest link. From the point of view of national security as a chain, we must state that its weakest link is tax security. This phenomenon is manifested due to the impossibility of a strong filling of the state budget, in particular, due to the existing risks that threaten tax security.

It seems that it was preferred not to mention the tax security of Ukraine during the whole period of independent Ukraine. In our opinion, the period of Ukraine's independence can be called a period of continuous procrastination in terms of legal security of tax security.

Key words: Tax Code of Ukraine, tax security, economic security, national security, research methodology. 